\title{
FORMULATION AND EVALUATION OF GREWIATENAX FRUITS AS EFFERVESCENT TABLETS FOR TREATMENT OF IRON DEFICIENCY ANEMIA
}

\section{${ }^{1}$ Elnazeer I. Hamedelniel, ${ }^{2}$ Hagir M. Omer, ${ }^{3}$ Qussai I. Balla, ${ }^{1}$ Yousif H-E. Y. Ibrahim, ${ }^{1}$ Fakhr Aldeen Y. Osman and ${ }^{* 4}$ Abdelmonem M. Abdellah}

\author{
1Department of pharmaceutics, Faculty of Pharmacy, Omdurman Islamic university, Omdurman, Sudan \\ ${ }^{2}$ Depetment of Chemistry, Faculty of Science, Jazan University, Kingdom of Saudi Arabia \\ ${ }^{3}$ Dept. of Environmental Health, Public Health Administration, Tabuk, Kingdom of Saudi Arabia, \\ ${ }^{4}$ Allahawi for Research Consultation (ARC), Khartoum North, Sudan
}

\section{ARTICLE INFO}

\section{Article History:}

Received $16^{\text {th }}$ November, 2019

Received in revised form

$03^{\text {rd }}$ December, 2019

Accepted $27^{\text {th }}$ January, 2020

Published online $29^{\text {th }}$ February, 2020

Key Words:

Grewiatenax, Iron content, Maceration, Granulation, Effervescent tablets.

*Corresponding author:

Abdelmonem M. Abdellah

\begin{abstract}
Grewiatenax fruits as nutritional supplement are being widely used in traditional medicine in most parts of Sudan to treat anemic patients. This study was conducted to specify the most productive method for extracting G. tenax fruits and to standardize and formulate the extract into effervescent tablets. The fruits were extracted by hot and cold extraction with maceration using $80 \%, 65 \%$, and $50 \%$ ethanol strength and the extracts were standardized. Two formulae (F1 and F2) were prepared from the extract and compressed into tablets. The formulated tablets were subjected for quality control tests. The $80 \%$ ethanol extract showed the highest extract yield and iron contents comparing to other extracts. The formulated tablets of both formulae showed good quality and pass all quality control tests.G. tenax fruitsextract could be pharmaceutically formulated into tablets which exhibited good quality control.To maximize yield value of $G$. tenax fruitsextract, maceration method using $80 \%$ ethanol strength is of paramount importance.
\end{abstract}

Copyright (C) 2020, Elnazeer I. Hamedelniel et al. This is an open access article distributed under the Creative Commons Attribution License, which permits unrestricted use, distribution, and reproduction in any medium, provided the original work is properly cited.

Citation: Elnazeer I. Hamedelniel, Hagir M. Omer, Qussai I. Balla, Yousif H-E. Y. Ibrahim, Fakhr Aldeen Y. Osman and Abdelmonem M. Abdellah. 2020. "Formulation and evaluation of grewiatenax fruits as effervescent tablets for treatment of iron deficiency anemia", International Journal of Development Research, 10, (02), 34084-34090.

\section{INTRODUCTION}

Plants remain the main source of medicines for a large proportion of the world's population, particularly in the developing world, despite the advent of the pharmaceutical chemistry during the early twentieth century (Ahmadet al., 2006). Aboagaribet al., (2014)reported that Grewiatenax (G. tenax) is one of the valuable plant species in Sudan and it is widely spread in arid area such as soil sand and near mountains, especially in the Savanna plantation area of the Northern and Middle of Sudan. G.tenaxbelongs to the family Tiliaceae which distributed throughout the western and eastern Sahelian zones, northern and southern Africa, the Arabian Peninsula and is also reported to grow from Iran to India on a wide array of soils, the juice made from its fruit is used as refreshing drink during the hot summer season (Gebaueret al., 2007).
It has been reported by Muhammad (2009)that due to its high iron content, fruits of $G$. tenaxare often used in special diets for pregnant women and anemic children and its leaves and twigs are palatable fodder for livestock and also important components of folk medicine for the treatment of trachoma, tonsillitis, infections and are used as a poultice to treat swelling. Gebaueret al. (2007) stated thatthe dry fruit pulp contains $6.3 \%$ crude protein, $0.4 \%$ fat, $8.1 \%$ fiber, $4.5 \%$ ash, and $15.1 \%$ starch and the iron content has attracted most attention which generally reaches $7.4 \mathrm{mg} / 100$ gram, the fruits also contain many other minerals such as sulfur $(0.1 \%)$, phosphorus $(0.08 \%)$, magnesium $(0.17 \%)$, calcium $(0.61 \%)$, sodium $(0.01 \%)$, and potassium $(1.45 \%)$, the pulp sweetness is provided by D-fructose $(24.3 \%)$, glucose $(21 \%)$, and sucrose (1.6\%).It was documented that $G$. tenax fruit contained higher amounts of crude protein, crude fiber and carbohydrates and its nutritional value lied in its good content of iron, ascorbic acid, D-fructose sugar and calcium (Sulimanet al., 2018). It has 
been reported that in traditional medicine leaves, root, and fruits of $G$. tenax are used for the treatment of digestive diseases, liver disorders, jaundice, and inflammatory conditions (Safa et al., 2012). Furthermore, it was stated that the administration of ethanol extract of $G$. tenax significantly restored $\mathrm{CCl}_{4}$ induced biochemical and histopathological changes and significantly reduced cholesterol, low-density lipoproteins, and triglycerides level (Safa et al., 2012) and attributed these effects to antioxidant and anti-inflammatory properties. Experimental studies in rats showed no adverse effect of ethanolic extract of $G$. tenxexcept mild diarrhea in the high dose of $2 \mathrm{~g} / \mathrm{kg}$ b.w.(Al-Asmariet al., 2014). Alzergy (2017) suggested that administration of $G$. tenax fruit for two weeks in traditional treatment inhibited oxidative effects resulted from formalin exposure and attributed that to flavonoids and other antioxidant constituents in this plant.

However, it has been reported that all parts of G.tenax are a rich source of medicinally useful components; the leaves are easily available in abundant amounts and have been intensively used in traditional medicine for the treatment of venous insufficiency, hemorrhoids, hypoglycemia, diarrhea and fungal or microbial infectionsSyeda (2014). The methanolic extract of $G$. tenax stem bark showed antibacterial activity against Bacillus sublilis bacteria (Aliet al., 2017).

On contrast, Ayed et al. (2015) concluded that enterohepatonephropathy is a characteristic feature of G.tenax toxicities in chicks and these lesions were correlated with changes in serum aspartate aminotransferase activity and concentrations of total protein, albumin, globulin, total bilirubin, cholesterol, uric acid, and calcium as well as with alterations in hemoglobin, packed cell volume, red blood cells, mean corpuscular volume and mean corpuscular hemoglobin concentration values. Effervescent tablets are uncoated tablets generally containing acid substances and carbonates or hydrogen carbonates, which react rapidly in the presence of water to release carbon dioxide (effervescence). They are intended to be dissolved or dispersed in water before administration (USP, 2009) and are used to obtain rapid drug action, or to facilitate the intake of the drug(Aulton, 2002). Beside that effervescent tablets can enhance the palatability of the drugs (James, 2007). On the other hand effervescent dosage forms are relatively expensive to produce and contain a high $\mathrm{Na}$ and/or $\mathrm{K}$ concentrations which can affect some patients populations under $\mathrm{Na}$ or $\mathrm{K}$ restriction (James, 2007). Therefore, this study was intendedto specify the best method of extraction through the yield value percentages and the elemental analyses for iron determination and to evaluate tablets of the formulae formed by the study.

\section{MATERIALS AND METHODS}

Collection of G. tenax fruits: First class freshly handpicked $G$. tenaxfruits were purchased from Omdurman City market, Khartoum, Sudan. The G. tenaxplant isgenerally grown inSouth Darfur, West of Sudan. They fruits were clean with bright reddish yellow color. Fruits were authenticated in Medicinal and Aromatic Plants Research Institute. Extraction and chemical analyses

\section{Extraction of $G$. tenax fruits}

Cold extraction method: Maceration was done according to Saeed and Elmubarak(1974), where 100 gm of clean and freshly collected Grewiatenax fruits macerated in $400 \mathrm{ml}$ of ethanol of different strengths $(50 \%, 65 \%$, and $80 \%)$, after removing solvents, the dried fruits extract was collected and the yield value of each concentration was calculated.

\section{Hot extraction methods}

Digestion method: Hot extraction was done according to Soxhelt (1879), where100gm of fruits was macerated in the same strengths of $80 \%, 65 \%$. and $50 \%$ ethanol.

Decoction method: A total of 100 gm of G. tenax fruit was washed with distilled water for 30 seconds and transferred into a $1 \mathrm{~L}$ glass flask, $450 \mathrm{ml}$ of distilled water was added and the flask content was heated at $100{ }^{\circ} \mathrm{C}$ for twenty minutes, then removed from the heater and the temperature allowed to fall down till reach $55^{\circ} \mathrm{C}$, the fruits were squeezed thoroughly and gently by hands and transferred into a glass beaker which contain $1.5 \mathrm{gm}$ of sodium benzoate dissolved in $5 \mathrm{ml}$ distilled water to prevent fermentation so that fermentation can be prevented, flask content was gently shaken for three minutes before filtration througha cotton pad, concentrated with a rotary evaporator and poured into Petri-dishes to drying at room temperature.

\section{Standardization of $G$. tenax extracts}

Physical characteristic of $G$. tenax extract: Extracts of $G$. tenax were subjected to sensory attributes (color, odor, consistency, taste and solubility in water) using hedonic scale. The results obtained by the panelists.

Yield value calculation of extraction methods: The yield value was calculated after the extract has been dried.

Ironanalysis: Iron analysis for extracts of $G$. tenax were prepared according to James (2007), where two parts by weight of Nitric acid and one part of perchloric acid were mixed with the crude fruits. $0.5 \mathrm{~g}$ of each air-dried $G$. tenaxfruits extract was accurately weighed, finely cut and homogeneously mixed in a clean silica crucible. $10 \mathrm{ml}$ of digestion mixture was added and placed in an oven, slowly heated to $100^{\circ} \mathrm{C}$ and maintained at this temperature for up to 3 hours, then heated to $120^{\circ} \mathrm{C}$ for 2 hours. The temperature rose very slowly to $240^{\circ} \mathrm{C}$, avoiding loses due to possible violent reactions especially in the temperature range of $160-200^{\circ} \mathrm{C}$, and maintained at this temperature for 4 hours, the remaining of dry inorganic residue dissolved in $10 \mathrm{ml}$ of nitric acid and transferred into $100 \mathrm{ml}$ volumetric flask and the volume completed with water. The samples were prepared in duplicate and the mean was calculated.

Isolation of $G$. tenax fruits extract: Isolation of $G$. tenax fruits extract done by using preparative thin layer chromatography (TLC), dissolved in a solvent and allowed to dry at room temperature, scanning was done using Ultra-Violet (UV) and Infra-Red (IR).

Tablets preparation of $\boldsymbol{G}$. tenax extracts: The already prepared extract of $85 \%$ ethanol was chosen to prepare the two types of tablets. Ingredients, which shown in Table 1, wereaccurately weighed and transferred to stainless steel pan. Citric acid, tartaric acid, methyl crystalline cellulose (MCC) and lactose was added to the extract, and thoroughly mixed with pestle for 45 minutes till the ingredients were homogeneously mixed, the wet mass was then forced manually through No.10 mesh screen. The formed granules were 
collected in aluminum plates and dried in a hot air oven at $55^{\circ} \mathrm{C}$ for 48 hour. On the other hand, the sodium bicarbonate was poured into other stainless pan and wetted with methanol, the wet mass was then forced through No.10 mesh screen and the formed granules were collected on aluminum plates and dried in a hot air oven at $55^{\circ} \mathrm{C}$ for 48 hours. All the dried granules were resized by forcing them through No. 32 mesh screen. Finally, (51 gm) of MCC was added and mixed thoroughly for 20 minutes. Orange color and flavor were dissolved in $35 \mathrm{ml}$ of methanol, filtered, packed into glass sprayer and sprayed on the granules and the sodium benzoate separately, with continuous mixing of the granules. The granules were then transferred to the oven at $75{ }^{\circ} \mathrm{C}$ for 25 minutes with mixing after each 5 minutes. The sodium benzoate was triturated with mortar and pestle until a homogeneous color and small particle size were obtained and thoroughly mixed with the granules bed.Preformulation studies were done for granules (particle size and distribution, powder flow ability and compressibility). The amount of MCC in F1 and F2 formulae were divided into 300 and 200gm in the granulation step and 51 and $49 \mathrm{gm}$ in the pre-compression step respectively. The bicarbonate was wetted with $10 \mathrm{ml}$ and $5 \mathrm{ml}$ methanol in formula $\mathrm{A}$ and $\mathrm{B}$ respectively.The formulation ingredients per tablet prepared by this study of formulae F1 and F2 were shown in table 1. The granule mixture was compressed into tablets using single punch tableting machine and lubricated with a small amount of liquid paraffin to prevent adhesion and chipping of tablet and promote smooth ejection, $20 \mathrm{~mm}$ die size was mounted and the compression force and lower punch level were adjusted, the in-process control was carried out to ensure constant weight of tablets, hardness and effervescence time. The formed tablets were collected and packed in well closed glass container.

Table 1. The formulation ingredients per tablet of formulae F1 and $F 2$ prepared by this study

\begin{tabular}{lcc}
\hline Materials & F1 & F2 \\
\cline { 2 - 3 } & Quant./tab(mg) & Quant./tab(mg) \\
\hline Extract & 511.00 & 511.00 \\
MCC powder & 585.00 & 415.00 \\
Lactose powder & 165.00 & 415.00 \\
Sodium benzoate & 80.00 & 0.00 \\
Citric acid (anhydrous) & 95.20 & 95.20 \\
Tartaric acid & 190.30 & 190.30 \\
Sodium bicarbonate & 323.50 & 323.50 \\
Orange color \& flavor & 50.00 & 50.00 \\
\hline
\end{tabular}

Quality control tests for formed tablets: Weight variation test, hardness test, friability test and disintegration time test for both formula were carried out, where six tablets were randomly taken from each formula, each tablet was placed in glass beaker containing $200 \mathrm{ml}$ distilled water at $28^{\circ} \mathrm{C}$. the time required to complete the effervescence reaction was calculated, and the average time was compared to the British Pharmacopoeia specifications (2009). Content uniformity test was also done, where ten tablets from both formulae were individually dissolved in $200 \mathrm{ml}$ distilled water at $28^{\circ} \mathrm{C}$ and analyzed using the UV spectrophotometer according to USP ${ }^{17}$, for calculation of content uniformity calibration curve was prepared (Figure 1).

\section{RESULTS AND DISCUSSION}

\section{Standardization of G. tenax fruits extracts}

Physical Characteristics: Physical Characters of the extracts were shown in table 2. Color: All colors of maceration and digestion extracts using ethanol $80 \%$ were deep yellow and the color was pale yellow of extracts using ethanol $65 \%$ while the color was tend to be pale brown of extracts using ethanol $50 \%$.

Odor: Odor was distinct in all extracts in different extraction methods.

Consistency: All of maceration extracts were moderately viscous, digestion extract of $80 \%$ ethanol strength was liquid and semisolid in both $65 \%$ and $50 \%$ ethanol strength digestion extracts, decoction extract was very viscous (plastic) while seemed to be sticky in extract using extraction method of maceration followed by freeze drying.

Taste: taste was sweet in all extracts using the different types of extraction methods.

Solubility in water: All extracts were soluble in water except extract of maceration followed by freezing, which was poorly soluble in water, while extract of decoction method was sparingly soluble in water (Table2).

\section{Calibration Curve (UV)}

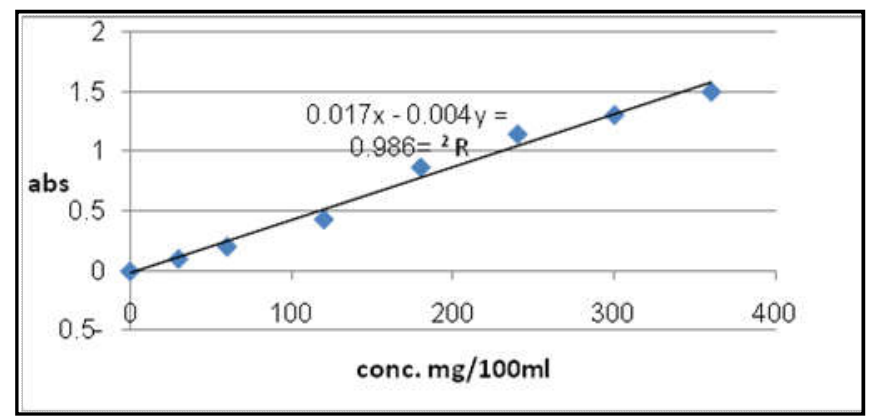

\section{Figure 1. The UV calibration curve of the $80 \%$} ethanol maceration extract

Yield value of extraction methods: Yield value of extraction methods of the Extracts were shown in table 3, the highest yield of extract was that of using maceration method of $80 \%$ methanol strength (35.70) seconded by digestion method (30.35) and then followed by decoction method (28.80), while the method of maceration followed by freeze drying showed the lowest extract yield value (22.60). It could be noticed that, in maceration extraction method, the yield value decreased by decreasing methanol strength. The highest yield value and the highest iron content of the extracts was obtained by maceration using ethanol $80 \%$; make this extract of best choice for formulation into pharmaceutical dosage form (effervescence tablet). On the other hand, Freeze drying and decoction methods produce no result in mineral analysis, this may be attributed to the formation of gel structure owning from higher temperature used in decoction method while the lower temperature in freeze drying may express the plastic consistency of both of the extracts obtained by these methods, in addition, adding sodium benzoate (to compact the microbial attack) to decoction method may alter chemical composition of the extract. Therefore, the selection of water as extraction solvent should be excluded. Digestion method of extraction (using ethanol 80\%) produces stable concentrated liquid which retains its initial characteristics for more than one year without any change in its appearance and consistency; therefore, it can be effectively and easily formulated as syrup dosage form as 
effective nutraceutical dosage form for children and elder patients suffer from iron deficiency anemia.
These values can be comparable to the result obtained by this study when using maceration extract by $65 \%$ methanol

Table 2 The physical characteristics of the extracts

\begin{tabular}{|c|c|c|c|c|c|c|}
\hline Extraction method & Ethanol strength & Color & Odor & Consistency & Taste & Solubility in water \\
\hline \multirow[t]{3}{*}{ Maceration } & $80 \%$ & Deep yellow & Distinct & Moderately viscous & Sweet & soluble \\
\hline & $65 \%$ & Pale yellow & Distinct & Moderately viscous & Sweet & soluble \\
\hline & $50 \%$ & Pale brown & Distinct & Moderately viscous & Sweet & Soluble \\
\hline \multirow{3}{*}{ Digestion } & $80 \%$ & Deep yellow & Distinct & Liquid & Sweet & soluble \\
\hline & $65 \%$ & Pale yellow & Distinct & Semisolid & Sweet & soluble \\
\hline & $50 \%$ & Pale brown & Distinct & Semisolid & Sweet & Soluble \\
\hline Decoction & - & Pale brown & Distinct & Very viscous (plastic) & - & Sparingly soluble \\
\hline $\begin{array}{l}\text { Maceration followed } \\
\text { by freeze drying }\end{array}$ & - & Pale yellowish-red & Distinct & Sticky & sweet & Poorly soluble \\
\hline
\end{tabular}

Table 3. The yield value for the extracts

\begin{tabular}{lcc}
\hline Extraction method & Alcohol percent & Yield value $\% \pm 2$ \\
\hline Maceration & $80 \%$ & 35.70 \\
& $65 \%$ & 27.81 \\
Digestion & $50 \%$ & 13.67 \\
& $80 \%$ & 30.35 \\
Decoction & $65 \%$ & 27.32 \\
Maceration followed by freeze drying & $50 \%$ & 31.52 \\
\hline
\end{tabular}

Table 4. Iron content of the extracts

\begin{tabular}{llll}
\hline Sample name & $\begin{array}{l}\text { Iron conc. /0.5 gram } \\
\text { Analysis 1 }\end{array}$ & $\begin{array}{l}\text { Iron conc. /0.5 gram } \\
\text { Analysis 2 }\end{array}$ & Mean Iron conc. /0.5 gram \\
\hline Maceration80\% ethanol & $35.20 \mu \mathrm{g}$ & $33.36 \mu \mathrm{g}$ & $34.28 \mu \mathrm{g}$ \\
Maceration 65\% ethanol & $20.37 \mu \mathrm{g}$ & $22.27 \mu \mathrm{g}$ & $21.32 \mu \mathrm{g}$ \\
Maceration 50\% ethanol & $18.16 \mu \mathrm{g}$ & $20.18 \mu \mathrm{g}$ & $19.17 \mu \mathrm{g}$ \\
Digestion 80\% ethanol & $14.17 \mu \mathrm{g}$ & $12.05 \mu \mathrm{g}$ & $13.11 \mu \mathrm{g}$ \\
Digestion 65\% ethanol & $05.78 \mu \mathrm{g}$ & $07.31 \mu \mathrm{g}$ & $06.55 \mu \mathrm{g}$ \\
Digestion 50\% ethanol & $05.10 \mu \mathrm{g}$ & $03.95 \mu \mathrm{g}$ & $04.53 \mu \mathrm{g}$ \\
\hline
\end{tabular}

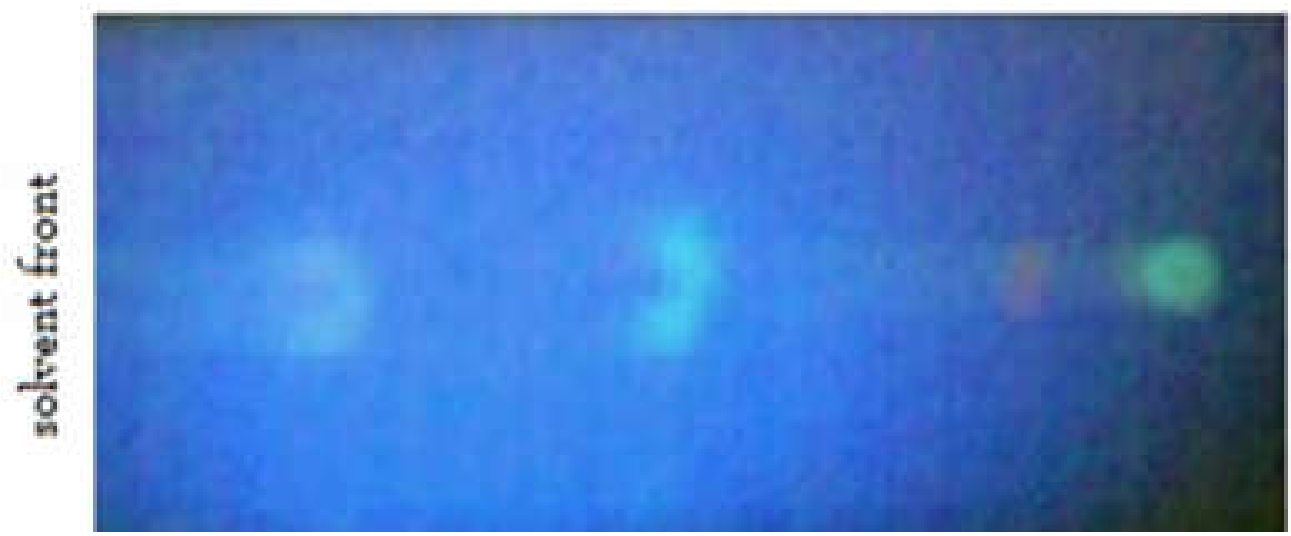

Figure 2. TLC chromatogram

Iron content: Iron content of extracts was shown in Table 4; the highest iron content was that of using maceration method of $80 \%$ methanol strength; mean value $(34.28 \mu \mathrm{g} / 0.5 \mathrm{~g})$, seconded by $65 \%$ methanol strength; mean value $(21.32$ $\mu \mathrm{g} / 0.5 \mathrm{~g}$ ) and then followed by $50 \%$ methanol strength; mean value $(19.17 \mu \mathrm{g} / 0.5 \mathrm{~g})$, while the digestion method showed iron values of $13.11 \mu \mathrm{g} / 0.5 \mathrm{~g}, 06.55 \mu \mathrm{g} / 0.5 \mathrm{~g}$ and $04.53 \mu \mathrm{g} / 0.5 \mathrm{~g}$ using $80 \%, 65 \%$ and $50 \%$ ethanol extract, respectively. Ali et al. (2016) reported that $G$. tenax fruits contain 21-30mg $\mathrm{Fe} / 100 \mathrm{~g}$ whereas Abdualrahmanet al.(2011) stated that $G$. tenax fruits were found to contain $25 \mathrm{mg} / 100 \mathrm{~g}$ iron. Mohammed Elhassan and Yagi(2010) investigated G. tenax fruits components and found that potassium showed higher content $(817 \mathrm{mg} / 100 \mathrm{~g})$ than calcium $(790 \mathrm{mg} / 100 \mathrm{~g})$ while iron was found to be $21 \mathrm{mg} / 100 \mathrm{~g}$. strength (mean value: $21.32 \mu \mathrm{g} / 0.5 \mathrm{~g}$ ), and lower than the result obtained by this study when using maceration extract by $80 \%$ methanol strength (mean value: $34.28 \mu \mathrm{g} / 0.5 \mathrm{~g}$ ). These results support the use of $G$. tenax in various region of the world with regard of the traditional treatment of anemia. The iron content present in $G$. tenax fruits not high enough to compensate the iron needs for patients suffer from iron deficiency anemia. Small amounts of iron in the presence of ascorbic acid (vitamin C) and the other phytochemical groups may be responsible for iron absorption from the extract, in addition, the presence of ascorbic acid in G. tenax fruits ${ }^{5}$ may act as absorption factor for dietary iron; this explains the increase in packed cell volume and elevation in haemoglobin concentration after taking $G$. tenax fruits. 


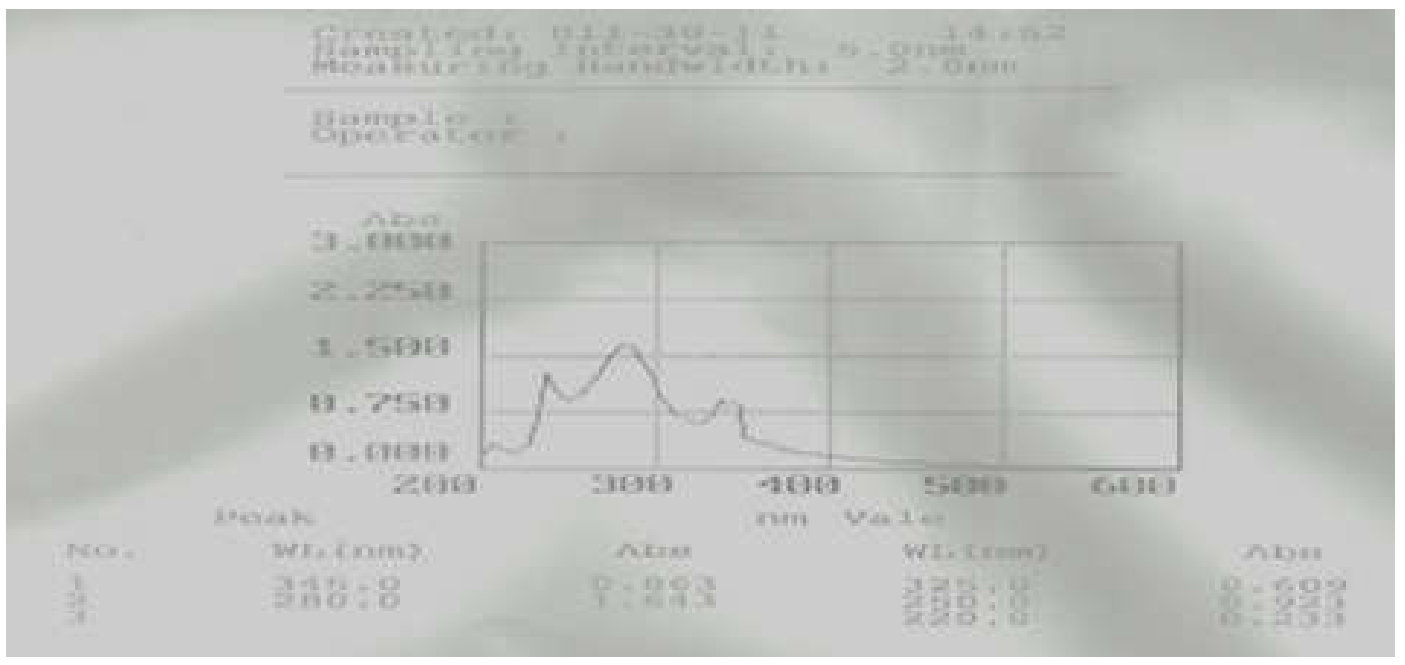

Figure 3. The UV scanning for the extract showed maximum absorbance at $280 \mathbf{~ m m}$

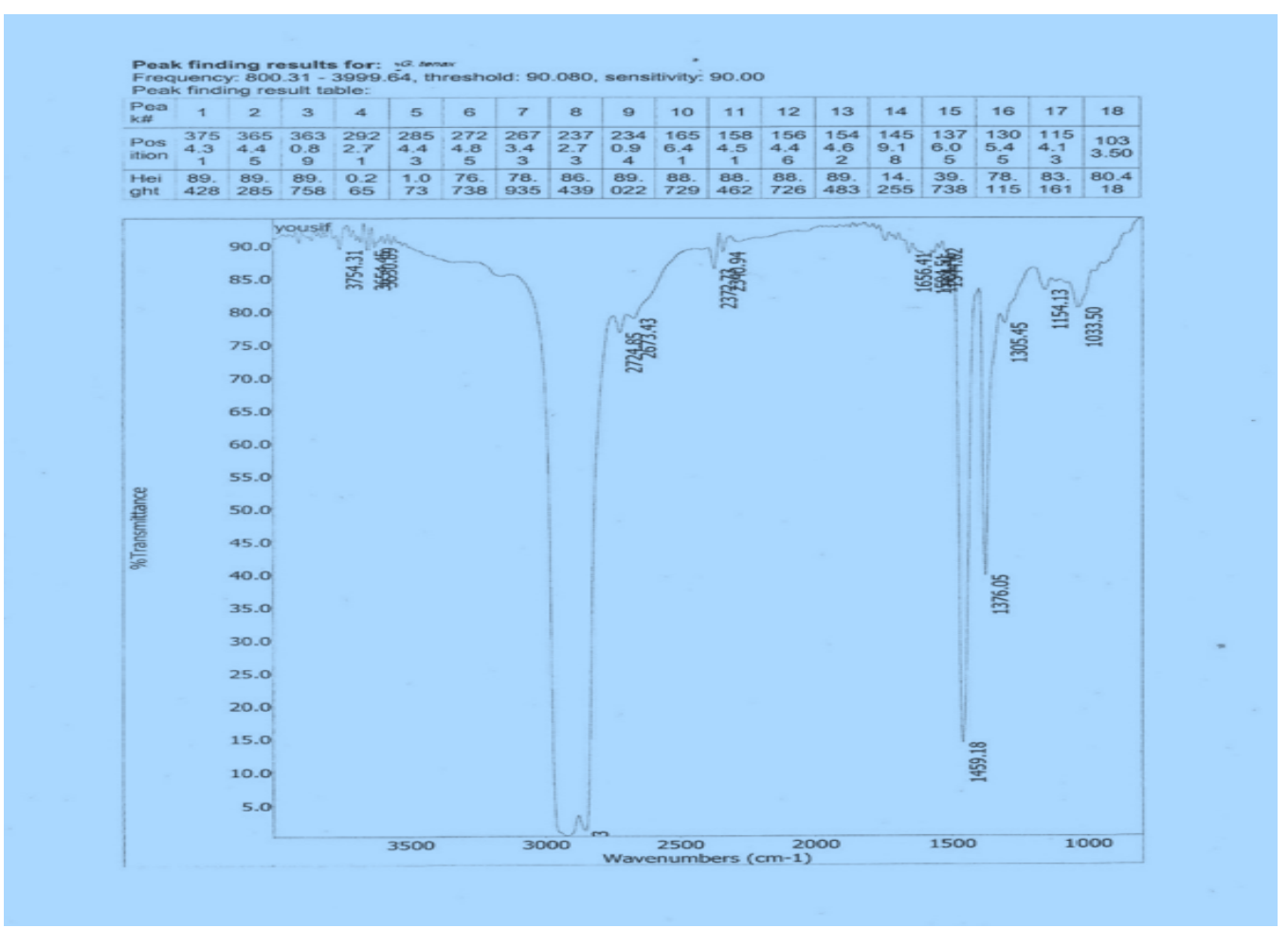

Figure 4. The IR spectrum for the G. tenaxextract

Table 4. The Angle of ribose, Carr's index for both F1 and F2 granules blend

\begin{tabular}{lcc}
\hline \multicolumn{1}{c}{ Parameter } & F1 & F2 \\
\hline Angle of ribose & $19^{\circ}$ & $27^{\circ}$ \\
Bulk Density $\left(\mathrm{g} \mathrm{cm}^{-3}\right)$ & 0.544 & 0.614 \\
Tapped Density $\left(\mathrm{g} \mathrm{cm}^{-3}\right)$ & 0.636 & 0.766 \\
Carr's Index \% & 14.465 & 19.843 \\
\hline
\end{tabular}

Granules flowability: Angle of ribose of granules showed that both of the prepared formulae were good, F1 was $19^{\circ}$ while F2 was $27^{\circ}$. Bulk Density, Tapped Density and carr's Index \% showed compliance to the recommended range of compressibility (Table 4).

Particle Size Analysis and Distribution: Particle size analysis of granules showed that both of the prepared formulae were in range, no remarkable differences noticed between the two formulae with regard to particle size and distribution (Table 5).
Quality control tests of tablets: Weight variation, hardness, friability, content uniformity and disintegration tests for both formulae were within the permitted limits from at zero time of tablet production up to three months after production at accelerated condition of temperature $\left(40^{\circ} \mathrm{C}\right.$ and $\left.75 \% \mathrm{RH}\right)$, this reflects the stability of both formulae (Table 6). Both formulae pass weight variation test, percent deviations for both formulae were within the limit (less than 5\%), Hardness test for both formulae were within the limits (more than $4 \mathrm{~kg}$ and less than $10 \mathrm{~kg}$ ), Friability test results for both formulae were within the limit (less than 1\%), Content uniformity test for both formulae 
Table 5: The particle size distribution of final- blended granules of both formulae

\begin{tabular}{llllll}
\hline $\begin{array}{l}\text { Mesh } \\
\text { No. }\end{array}$ & $\begin{array}{l}\text { Aperture Size } \\
\text { Range / Mean }(\mu \mathrm{m})\end{array}$ & F1 & F2 & Weight $(\mathrm{gm})$ \\
\cline { 3 - 5 } & & $\begin{array}{l}\text { Percent } \\
\text { or Frequency }\end{array}$ & $\begin{array}{l}\text { Feight }(\mathrm{gm}) \\
\text { or Frequency (\%) }\end{array}$ & $\begin{array}{l}\text { Percent } \\
\text { Frequency (\%) }\end{array}$ \\
\hline 24 & $600-850 \mu \mathrm{m}, 710 \mu \mathrm{m}$ & 0.60 & 6.38 & 0.40 & 04.30 \\
32 & $425-600 \mu \mathrm{m}, 500 \mu \mathrm{m}$ & 1.80 & 19.15 & 2.10 & 22.58 \\
42 & $300-425 \mu \mathrm{m}, 355 \mu \mathrm{m}$ & 3.30 & 35.11 & 2.30 & 24.73 \\
60 & $212-300 \mu \mathrm{m}, 250 \mu \mathrm{m}$ & 2.50 & 26.60 & 3.10 & 33.33 \\
80 & $150-212 \mu \mathrm{m}, 180 \mu \mathrm{m}$ & 0.70 & 7.45 & 0.60 & 6.45 \\
100 & $125-180 \mu \mathrm{m}, 150 \mu \mathrm{m}$ & 0.50 & 5.32 & 0.80 & 8.60 \\
\hline
\end{tabular}

Table 6. Mean variation of tablets quality control tests

\begin{tabular}{|c|c|c|c|c|c|c|c|c|c|}
\hline \multicolumn{2}{|c|}{$\begin{array}{l}\text { Weight variation } \\
\text { wt. }(\mathrm{g})\end{array}$} & \multicolumn{2}{|c|}{$\begin{array}{l}\text { Friability test } \\
\text { \%weight loss)( }\end{array}$} & \multicolumn{2}{|c|}{$\begin{array}{l}\text { Hardness } \\
\mathrm{kg})(\end{array}$} & \multicolumn{2}{|c|}{$\begin{array}{l}\text { Content Uniformity } \\
\text { Content } \%)(\end{array}$} & \multicolumn{2}{|c|}{$\begin{array}{l}\text { Disintegration time } \\
(\mathrm{min} .)\end{array}$} \\
\hline F1 & $\mathrm{F} 2$ & $\mathrm{~F} 1$ & $\mathrm{~F} 2$ & $\mathrm{~F} 1$ & $\mathrm{~F} 2$ & $\mathrm{~F} 1$ & $\mathrm{~F} 2$ & $\mathrm{~F} 1$ & $\mathrm{~F} 2$ \\
\hline 2.038 & 2.032 & 0.792 & 0.812 & 7.131 & 6.092 & 102.488 & 103.347 & 2.34 & 2.67 \\
\hline
\end{tabular}

was within the limits (not less than $85 \%$ and not more than $115 \%$ ), and effervescence time test (disintegration test) was also within the specified time (less than 5 minutes). The effervescence time test can be considered as disintegration test and dissolution test because, the tablet was completely soluble within the specified time for effervescence.

\section{Conclusion}

The $80 \%$ ethanol extract showed the highest extract yield and iron contents comparing to other extracts, to maximize yield value of $G$. tenax fruitsextract, maceration method using $80 \%$ ethanol strength is of paramount importance. The formulated tablets of both formulae showed good quality and pass all quality control tests. G. tenax fruitsextract could be pharmaceutically formulated into tablets which exhibited good quality control.

Acknowledgement: The authors acknowledge the assistance of all those who contributed to this study

\section{REFERENCES}

Abdualrahman, M.A.Y., Ali O.S. and Suliman, A.M.A. 2011. Nutritional Evaluation of Guddaim Fruits (Grewiatenax) and its Utilization in Ice Cream Production Nutritional Evaluation of Guddaim Fruits (Grewiatenax) and its Utilization in Ice Cream Production, Journal of Science and Technology 12 (03), 38-43, December 2011, www.sustech.edu.

Aboagarib, E.A.A., Yang, R., Hua, X., Siddeeg, A. 2014. Chemical compositions, nutritional properties and volatile compounds of Guddaim (GrewiatenaxForssk) Fiori fruits J. Food Nutr. Res. 2(4), 187-192.

Ahmad, I., Aqil, F. and Owais, M. 2006. Modern Phytomedicine, Turning Medicinal Plants into Drugs. ISBN: 978-3-527-31530-7, https://onlinelibrary. wiley.com/doi/book/10.1002/9783527609987

Al-Asmari, A.K., Al-Elaiwi, A.M., Tanwir Athar, M.D., Tariq, M., AlEid, A., and Al-Asmary, S.M. 2014. A Review of Hepatoprotective Plants Used in Saudi Traditional Medicine. Hindawi Publishing Corporation EvidenceBased Complementary and Alternative Medicine Volume 2014, Article ID 890842, 22 pages http://dx.doi.org/ $10.1155 / 2014 / 890842)$.
Ali, H.A., Salih, S.A., Ahmed, O.E. and Hamza, A.A. 2017. Biological activity and phytochemical profiling of Grwiatenax stem bark extracts. International Journal of Biology, Pharmacy and Allied Sciences (IJBPAS), 6(6): 1181-1194

Alzergy, A.A. 2017. Effect of aqueous extracts of Grewiatenax fruit (guddaim) on hematological, histological and ultrastructure changes in mice intoxicated with formalin, Nature and Science 2017 ;15(12), 176-193. http://www.sciencepub.net/nature.

Aulton, M.E. 2002. Pharmaceutics the science of dosage form design, second edition, 2002.

Ayed, I.A.M., Shalaye, M.H.F., Kheder, S.I., Huneif, M.A. and Ali, A.E. 2015. Effects of Dietary Grewiatenax (Goddaim) Fruit and its Ethanolic Extract Given by Different Routes of Administration on Bovans-Type Chicks. Int. J. Curr. Res. Biosci. Plant Biol. 2015, 2(4): $143-150)$ )

Gebauer, J. K. El-Siddig, E.1., Tahir, B. A., Salih, A., Ebert, G. and Hammer, K. 2007. Exploiting the Potential of Indigenous Fruit Trees: Grewiatenax(Forssk.) Fiori in Sudan, Genet Resource Crop E vol. 54:1701-1708.

James, S. 2007. Encyclopedia of P Pharmaceutical Technology, Third Edition, volume one, copy right by Informa Healthcare USA, Inc.

Mohammed Elhassan and Yagi, S.M. (2010). Nutritional Composition of Grewia Species (Grewiatenax (Forsk) Fiori, G. flavescensJuss and G. VillosaWilld) Fruits, Advance Journal of Food Science and Technology 2(3): 159-162, 2010.

Muhammad, S. 2009. Ecophysiology of seed dormancy and salt tolerance of Grewiatenax(Forssk.) Fiori and Ziziphusspina-christi(L.) Willd. Organic Plant Production and Agroecosystems Research in the Tropics and Subtropics, University of Kassel, Steinstr.19, 37213 Witzenhausen, Germany.

Saeed, A. and Elmubarak, A. 1974. A guide to manufacture of jams industry, Technical Report No.3 Food Research Center, 1974, Khartoum, Sudan.

Safa, O., Soltanipoor, M.A., Rastegar, S., Kazemi, M., Nourbakhsh Dehkordi, K. and Ghannadi, A. 2012. "An ethnobotanical survey on Hormozgan province, Iran," Avicenna Journal of Phytomedicine, vol.3, no.1, pp.6481, 2012.

Soxhlet, F. 1879. "Die gewichtsanalytischeBestimmung des Milchfettes". Dingler's Polytechnisch. J. (in German) 232, $461-465$ 
Suliman, Z.E.A., Zidan, N.S. and Foudah, S.H.I., 2018. Chemical Compositions, Antioxidant, and Nutritional Properties of the Food Products of Guddaim (Grewiatenax). International Journal of Pharmaceutical Research \& Allied Sciences, 2018, 7(3):172-182. www.ijpras.com

Syeda, J. B. T., Subba Reddy, G.V., Jayaveera, K.N. 2014. Anthelmintic activity of crude extract of Grewiatenax. World J. Pharm. Pharmaceut. Sci. 3(8), 1710-1715.
USP, United States Pharmacopeia, 2008. Disintegration Test of Tablet, p 1-3. https://pdfs.semanticscholar.org

USP, United States Pharmacopeia, 2009. Uniform Content and Weight Variation 905, 30(4): 1595-1599, 2009. https://www.usp.org

$* * * * * * *$ 